\title{
Identification of risk factors leading to cost and time overrun in B-O-T projects.
}

\section{Identificación de factores de riesgo que conducen a un exceso de tiempo y costos en Proyectos B-O-T}

\author{
Neena S Lal, Anue Marry Mathew \\ Department of Civil Engineering, TOC H Institute of Science and Technology, Ernakulam \\ (Kerala), India. Corresponding author mail id: neenaslal91@gmail.com
}

\begin{abstract}
As infrastructural investments are vital in developing countries, it'll not solely facilitate to foster the economic growth of a nation, however it'll additionally act as a platform within which new kinds of partnership and collaboration may be developed. The developments of BOT have attracted participation of native and foreign non-public sector capitalist to secure funding and to deliver projects on time, within the budget and to the desired specifications. There are many complexities in projects because of the variety of factors in project's trend and also the dependence of project primarily on national factors. Because of these complexities and their long-term operation, the projects meet with uncertainty and numerous risks. Effective risk management methods and good managerial skills are required in guaranteeing the success of the project. In recent years, due to substantial increase in the amount of construction companies along with the changes in the government administrations, the construction projects are exposed to cost and time overrun and has huge impact on the progress of works within the industry. Although, the sector is considered to be a key driver of economic growth, time and cost overruns threaten to limit the sector's potential to help achieve the desired growth and ensure efficient capital expenditure.

Keywords-BOT, cost overrun, delays, risk.

\section{RESUMEN}

Las inversiones en infraestructura son vitales en los países en desarrollo, no solo facilitarán el fomento del crecimiento económico de una nación, sino que además actuarán como una plataforma dentro de la cual se pueden desarrollar nuevos tipos de asociación y colaboración. Los desarrollos de BOT han atraído la participación de capitalistas nacionales y extranjeros del sector no público para asegurar el financiamiento y entregar proyectos a
\end{abstract}


Sustainability, Agri, Food and Environmental Research, (ISSN: 0719-3726), 10(X), 2022:

http://dx.doi.org/

tiempo, dentro del presupuesto y con las especificaciones deseadas. Hay muchas complejidades en los proyectos debido a la variedad de factores en la tendencia del proyecto y también a la dependencia del proyecto principalmente de factores nacionales. Debido a estas complejidades y su operación a largo plazo, los proyectos enfrentan incertidumbre y numerosos riesgos. Se requieren métodos eficaces de gestión de riesgos y buenas habilidades de gestión para garantizar el éxito del proyecto. En los últimos años, debido al aumento sustancial en la cantidad de empresas constructoras junto con los cambios en las administraciones gubernamentales, los proyectos de construcción están expuestos a sobrecostos y tiempos y tiene un gran impacto en el avance de las obras dentro de la industria. Aunque se considera que el sector es un impulsor clave del crecimiento económico, los excesos de tiempo y costos amenazan con limitar el potencial del sector para ayudar a lograr el crecimiento deseado y garantizar un gasto de capital eficiente.

Palabras clave: BOT, sobrecoste, retrasos, riesgo

\section{INTRODUCTION}

Infrastructure investments are important in developing countries as it improves the economic growth of the country. The Public-Private Partnerships (PPP), which is essentially an agreement or contract, may be a way for developing the country's infrastructure. There are different types of PPP contracts, one among that are Build Operate Transfer or B-O-T. The BOT scheme is actually a sort of leasing, where the government (project sponsor) allows a private entrepreneur (project promoter) to design, finance, and build an infrastructure facility. In return, the project promoter is permitted to collect tolls (user fee) and operate the facility for a specific period (called the concession period), during which he is expected to recover all of his expenses and earn a reasonable profit. At the end of the concession period, the ownership of the facility is transferred to the government. This arrangement facilitates the implementation of capital-intensive infrastructure projects by the government with funds from outside the budget allocation, while transferring the risks involved to the private sector. Risk in BOT project is solitary and different but somehow always related to the phases in a project namely: initiation, implementation and operational phase. In order to accomplish the objectives, the risks need to be managed wisely.

The construction industry being one of the most complex, fragmented, schedule and resource driven industry, is always facing serious problems like low productivity, low quality, delay, cost overrun etc. Cost overrun in construction is a worldwide phenomenon, and its effects are normally a source of friction between owners, project managers, and contractors. As the construction industry continues to grow in size, so do planning and budgeting problems. 
Sustainability, Agri, Food and Environmental Research, (ISSN: 0719-3726), 10(X), 2022:

http://dx.doi.org/

This is because it is common for projects not to be completed on time and within the initial project budget. It is noted that there were more cases of cost overruns than time overruns. This makes the problem of cost overruns to be of great significance. In fact, it is one of the most important challenges facing the construction industry today. An out-of-control construction cost adds to investment pressure, increases construction cost, affects investment decisionmaking and wastes the national finance.

The key success indicators of construction management systems include completing the project with cost and time, within the planned budget and duration, and within the required quality, safety, and environmental limits. These goals are interrelated where each of them is affecting and affected by the others. An accurate cost estimating and scheduling should be sought in order to meet the overall budget and time deadline of a project.

\section{RISKS IN BOT PROJECTS}

The risks involved in BOT projects are two-fold. First, there are risks involved with the start-up procedure, (financial and technical studies), and also construction and operational risks due to the nature of BOT approach; and secondly, being large-scale projects, there are also regulatory, political and economical risks involved. As compared with other project delivery methods, risk management in BOT projects is more complicated because of the wider scope of work, the length of the concession period, and the scope of contractual responsibilities undertaken by the project sponsor. In general, the primary risks associated with a BOT project can be broadly grouped into two major categories, general risks and project-specific risks.(Kang C.C et.al 2009).

General risks are defined as those risks related to the macro-environmental factors of the host country such as the political environment, economic condition, the legal system, taxation, or fluctuations in currency exchange rate. These risks may severely affect the concession agreement and the project's cash flow during the lifetime of a BOT project. These general risks can be subdivided into political risks, financial risks, and legal risks.

Political risks are associated with the host country's political environment. These risks can be divided into two categories, sovereign risks and instability risks. Sovereign risks include expropriation of assets by the government, restriction of operating freedom, increased taxes or other financial penalties and other government interference that could jeopardize the project. Instability risks relate to cancellation or revision of contracts and damage to property or injury to personnel from terrorism or riot.(Sivagami.M et.al 2019) 
Sustainability, Agri, Food and Environmental Research, (ISSN: 0719-3726), 10(X), 2022: http://dx.doi.org/

Financial risks relate to the host country's economic environment such as currency devaluation, foreign exchange fluctuation, fluctuation in interest rates, and inflation.These risks affect the cost of debt service and the real value of the project revenue. Legal risks relate to the host country's changes in the legal system during the concession period. The success of a BOT project is dependent on contractual agreements and financing arrangements undertaken to support the project. Thus, any host country legislation modifying tax codes, environmental regulations, labor regulations, import restrictions, and corporate regulations may undermine the long-term viability of a BOT project.

Unlike the general risks, project-specific risks can be controlled by the project participants. These risks can be best identified and analyzed when classified by the different project stages, which are development, construction, and operation.

Development stage risks refer to the many uncertainties that may arise at the beginning of the project. These risks include defects in the request for proposal; planning and approval delays; errors in economic, environmental, or technological assessment; and rejection of the proposal by the granting authority. The most important of these risks is losing the tender to another proposing sponsor.

Construction stage risks primarily relate to delays in completion and cost overruns.Construction delays may be caused by technical difficulties, by poor management, or by a combination of both. Since BOT investors rely on income from the completed project to recover their investment, any delay in completion will delay the generation of revenue. Cost overruns will impact the profitability of the project by increasing construction and financing costs.

Operation stage risks relate to increased cost of operation and insufficient revenue from the completed project. Actual operation and maintenance costs may exceed those anticipated during project planning. The revenue risk has two components, demand risk and price risk. The demand risk is the uncertainty regarding the demand for the product or service provided by the completed project. The price risk is the price that realistically can be charged for the product or service. (Budayan C et.al 2019)

\section{RISK FACTORS CAUSING COST AND TIME OVERRUN}

Infrastructure plays a primary role in a country's economic growth. Investments in infrastructure in India have risen on a steady basis. While the sector is considered to be a key driver of economic development, time and cost overruns threaten to restrict the ability of the sector to help achieve the desired growth and ensure productive capital expenditure. The 
Sustainability, Agri, Food and Environmental Research, (ISSN: 0719-3726), 10(X), 2022:

http://dx.doi.org/

shortage of trained project managers could be considered as the root cause of time and cost overruns in a project lifecycle. The influx of talent in the infrastructure sector has also been shown to be diminishing, which also leads to cost and time overrun.

$>$ Major factors causing schedule overruns

- The primary explanation for schedule overruns in the pre-execution process is delays in land acquisition and site handing over.

- Manifold regulatory approvals from different agencies that lead to construction delays.

- Bad schedule management leads to ineffective communication with other programs and delays in scheduling.

- Insufficient project design/scope change management is commonly prevalent in the infrastructure industry.

- Insufficient supply of competent project managers, limited availability of qualified labor, lack of suppliers of good equipment and contractors, etc.

- Inefficient management of contracts leading to contractual conflicts and issues with labour relations and regulations slowing down project development.

$>$ Major factors causing cost overrun

- Scope creep and inadequate Detailed Project Report DPR are primary factors impacting cost overruns.

- With increasing importance of environmental safeguards, projects require additional budgets.

- Material price escalation beyond projections is the primary reason for cost overruns during execution.

- Lack of efficient transportation and logistics infrastructure adds to the project cost.

- Inadequate availability of skilled resources forces companies to pay high compensations for existing work forces, leading to cost overruns.

- Other factors such as weak procurement planning wrong or poor selection of technology etc. adversely impact the project costs. (Meng Q et.al 2017)

Due to delay and cost overrun along with other factors contributes to shutting down the projects mid way. One such case is that construction of an Offshore Container Terminal at Mumbai Port Trust.It was the first container privatization project at the Mumbai port. The project involves construction financing, equipping, operations and management of the offshore container terminal in the Mumbai Harbor on a Build Operate Transfer basis. The project is awarded to Indira Container Terminal Pvt. Ltd (ICT), which is a joint venture between Gammon 
Sustainability, Agri, Food and Environmental Research, (ISSN: 0719-3726), 10(X), 2022: http://dx.doi.org/

Infrastructure Projects Ltd, Gammon India Ltd and Dragados SPL of Spain for a 30-year concession period.

The project was approved in November 2007 with planned completion date of December 2010 with an estimated cost by both MbPT and ICT are 445 crores and 1016 crores respectively. Whereas in the revised estimate prepared on 2012, final cost was increased by 610 crores and 1429 crores with an expected completion date on 2013 December with a delay of around 36 months. If the project was completed then on financial front the project cost was expected to increase by 40 percent from INR 1461 crore to INR 2040 crore. A schedule was prepared in 2013 in order to complete the work by 2016 as shown in fig 1. Whereas in 2018 the project was planned for re bidding because of financial crisis and Gammon Infrastructure Projects, the developer for Indira Container Terminal Private Ltd at the Mumbai Port Trust, has planned to make a one-time settlement.

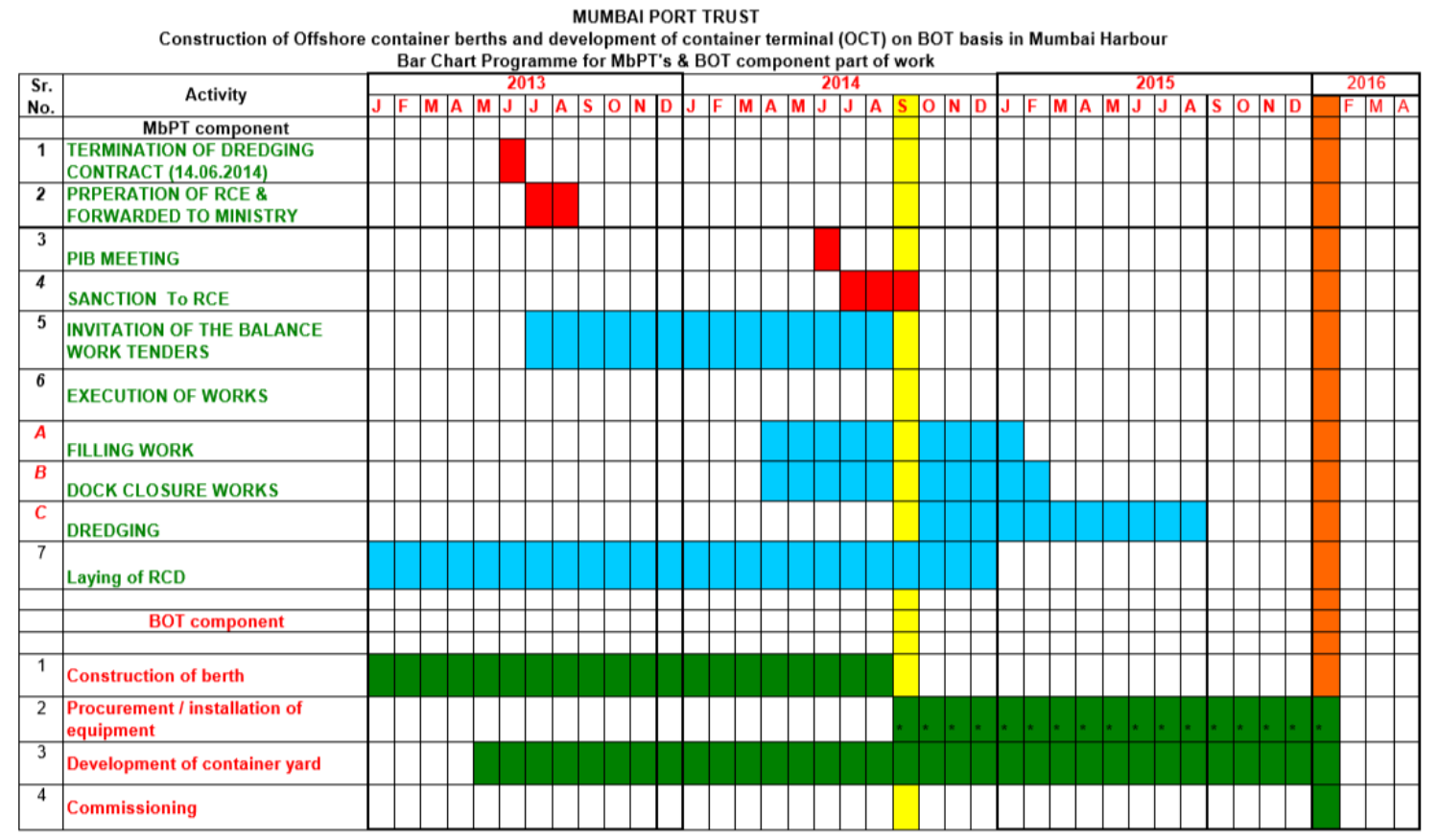

Fig 1: Planned schedule of work [Wikipedia]

$>$ Factors results in schedule and cost overrun in the project

- Delay in financial closure - Due to 2008 global recession banks put stringent norms for project financing, thus delaying the process of financial closure by 5.5 months

- More dredging work than estimated - Due to inaccurate estimates during planning phase the actual rock dredging quantity was much more than estimated. 
Sustainability, Agri, Food and Environmental Research, (ISSN: 0719-3726), 10(X), 2022:

http://dx.doi.org/

- Slow mobilization by EPC contractor - EPC Contract was signed on 2 December 2008; however, the actual work commenced only from 12 May 2009causing a delay of 5 months.

- Delay in project site handover - MbPT delayed the handing over of this area to the contractor by 4 months due to some incomplete work on the existing dock.

- Delay in awarding dredging work contract - Delay in tendering process occurred as the eligibility criteria were revised based on the standardization committee's recommendations which requires additional government approval leading to project delay.

- Delay in completing work by dredging contractor - The contractor had to complete dredging in berth pocket by October 2009, filling of P\&V Dock basins by June 2010 and dredging in approach channel by April 2011. However, the contractor missed the targets due to delay in deployment of dredgers, slow progression of work and other factors leading to delay of 18 months.

- Lack of integrated project master schedule - The project is divided into two packages i.e., dredging and berth construction and both these activities have individual project schedule. These schedules are not integrated to make a single project schedule.

- Delay in obtaining security clearance - The security clearance for the bidder was received after a period of 18 months from the Central government.

Whereas in some projects delays in schedule tends to huge increase of the capital, which also contributes to high debt ratio to the total project cost. Thiruvananthapuram City Roads Improvement Project at Kerala is an example.TRDCL is a Joint venture of IL\&FS Transportation Networks Limited (ITNL) and Punj Lloyd Limited responsible for implementation of First City Roads Improvement Project (TCRIP) on Build-Operate-and Transfer (Annuity) Model. The Scope of the Project includes: Improvement of $43 \mathrm{~km}$ of city road in Thiruvananthapuram. The project was implemented in four phases. The concession was awarded on a build-operate-transfer (BOT) annuity basis. The first phase was awarded way back in 2004 and was commissioned in November 2006 while the second phase was awarded in June 2009 and commissioned in February 2012. As by November 2016, development of 17 corridors having a total length of $42.069 \mathrm{~km}$ had been completed in 4 phases. Now the project is in 15-year Operation \& Maintenance stage.

The initial estimated project cost was Rs105 crores in 1999 but it was revised to Rs165 crores in 2003. As of May 2016, the total project cost stood at Rs 3.6 billion. ITNL has put in 
Sustainability, Agri, Food and Environmental Research, (ISSN: 0719-3726), 10(X), 2022:

http://dx.doi.org/

an equity amount of Rs 684.1 million. The debt portion stands at Rs 1.22 billion, about 34 per cent of the total project cost. The delay in work under Phases II and III of the TCRIP, especially between 2006 and 2009, put a lot of pressure on the funding agencies. As per ITNL, the annuity received for Phases I, II and III for 2014-15 stood at Rs 291.1 million. Meanwhile, the gross revenue and loss for 2014-15 were recorded at Rs 387.77 million and Rs 194.91 million respectively. Further, ITNL reported Rs 38 million as the annuity receivable per annum for the first phase of the TCRIP and Rs 25 million as the annuity accrued for the January-March quarter of 2015-16.

Factors results in schedule and cost overrun in the project

- Delay in land acquisition - Kerala PWD has not been able to hand over land as per its obligation in the concession agreement, resulting in severe project delays and repeated renegotiations of the contract.

- The social, political, and regulatory risks from the people - As the project had to be executed in the midst of highly literate people with heightened political awareness

- Violations from environmentalists and Human Rights groups - Sine the project had to follow several environmental safeguards along with safety and insurance of the workers.

- Legal/Contractual Issues - The full stretch of land required for project execution was to be handed over free of all encumbrances before November 2005. However only about $14 \mathrm{~km}$ was actually handed over leading to a pre-termination notice by TRDCL in July 2006. Following a series of negotiations, the first Resumption Agreement was signed in January 2008. A second Resumption Agreement was executed in May 2009 for completing the balance $28 \mathrm{~km}$ stretch and the completion of works for the remaining $10 \mathrm{~km}$ stretch by May 2011.

- Fair impact of operational risk, influence of currency exchange, interest rate etc.

\section{MITIGATION STRATEGIES}

Periodic review and oversight are one of the most commonly adopted strategies to control project schedule delay. This is primarily because BOT projects generally span over a long duration and hence require regular progress review. The nature of risk involved in such projects also keeps evolving constantly. Hence proactive risk assessment is required at the various stages of the project. Project reviews by third parties is another technique to review projects. Independent reviews by third parties provide an objective opinion on the project scope, budget, timelines, design, procurement, technology and contractor selection etc. Further this could help in bringing new ideas and break short sighted thinking. Due to the long 
Sustainability, Agri, Food and Environmental Research, (ISSN: 0719-3726), 10(X), 2022:

http://dx.doi.org/

gestation period of BOT projects, including of cost escalation clause as a part of the contract agreement would be an important strategy. Further developing cost effective project designs and joint evaluation of project design for value engineering is also used frequently. Regulatory Framework and Guidelines and Support from Government can prevent land acquisition problems and complicated procedure clearances from the authority in concern. Swift Courts for Dispute Resolution, Standard Phase Evaluation for issues related to change of scope. Usage of stable currency ie; local currency and proper risk management teams can be adopted for financial crisis and delays.

\section{CONCLUSION}

Each BOT project is exposed to various risks. It has thus become the duty and responsibility of the promoter to minimize the risks by hiring a strong management team to ensure the success of a BOT project. The greatest likelihood of a good outcome for a BOT project is obtained when both stakeholders share the substantial efforts and costs involved in the process of risk study. BOT projects are extremely vulnerable to lengthy delays and cost overruns. Cost overruns are fuelled by frequent design changes and poor preparation of procurement, which can be mitigated by sufficient project manager training and coaching. Delays in building can be caused by technological problems, bad governance, or a combination of both. In order to recover their investment, because BOT investors depend on the income from the completed project, any delay in completion would delay revenue generation. In order to mitigate these risks, the private sector enters into a fixed turnkey arrangement with the contractor that addresses this risk and then the risk goes to the contractor who should be able to manage it. It can be inferred that thorough risk assessment should be carried out for every BOT project and that the mitigation strategy must be strictly implemented to ensure the project's success.

\section{REFERENCES}

Budayan, C. (2019). Evaluation of Delay Causes for BOT Projects Based on Perceptions of Different Stakeholders in Turkey. Journalof Management in Engineering. Vol 35.

Durdyev, S., Omarov, M., Ismail, S. (2017). Significant contributors to cost overruns in construction projects of Cambodia. Cogent Engineering.

El-Karim, M.S.B.A, Abdel-Alim, A.M. (2017). Identification and assessment of risk factors affecting construction projects. Housing and Building National Research Center, Vol 13, pp 112-132. 
Sustainability, Agri, Food and Environmental Research, (ISSN: 0719-3726), 10(X), 2022:

http://dx.doi.org/

Kang, C.C, Feng, C.M.,(2009). Risk measurement and risk identification for BOT projects: A multi-attribute utility approach. Mathematical and Computer Modelling, Vol 49.

Kang, C.C, Feng, C.M, Kuo C.Y, (2011). A royalty negotiation model for BOT (build-operate transfer) projects: The operational revenue-based model. Mathematical\& Computer Modelling, Vol 54.

Meng, Q., Lu, Z.,(2017). Quantitative analyses of highway franchising under build- operatetransfer scheme: Critical review \& future research directions. TransportationResearch Part B, Vol 102, pp 105-123.

Menheere S.C.M, (2010). Case studies on Build-Operate-Transfer. Project Management and Real Estate Development.

Pehlivan S, Oztemir A.E., (2018). Integrated Risk of Progress-Based costs\&schedule delays in Construction Projects. Engineering Management Journal.

RahmanI.A.,Jaber M.M.,(2018). Risk assessment of time \&cost overrun factor throughout Construction Project Lifecycle: Pilot Study. International Journal of Engineering and Technology, Vol 7(3.20), pp 717-723.

Sivagami.M, Sarath. I.P, (2019). Risk Management In Construction Projects With Respect To Different Procurement Option. (IRJET), Vol 6(4).

Xenidis, Y., Angelides, D., (2005). The financial risks in Build - Operate - Transfer- projects. ConstructionManagement and Economics Vol 23 pp 431-441.

Xueqing Z., (2005). Critical Success Factors for Public-Private Partnerships in Infrastructure Development. Journal of Construction Engineering and Management, Vol 131.

Yang J.B, Yang C.C, Kao C.K (2010). Evaluating schedule delay causes for PPPconstruction works under the Build - Operate-Transfer model. International Journal of Project Management Vol 28 pp 569-579.

Zhang, X, (2005). Criteria for Selecting the private sector partnershipin the Public -PrivatePartnership. Journal of Construction Engineering and Management. Vol 13.

Received: 30th January 2021; Accepted: $11^{\text {th }}$ March 2021; First distribution: 01th April 2021 